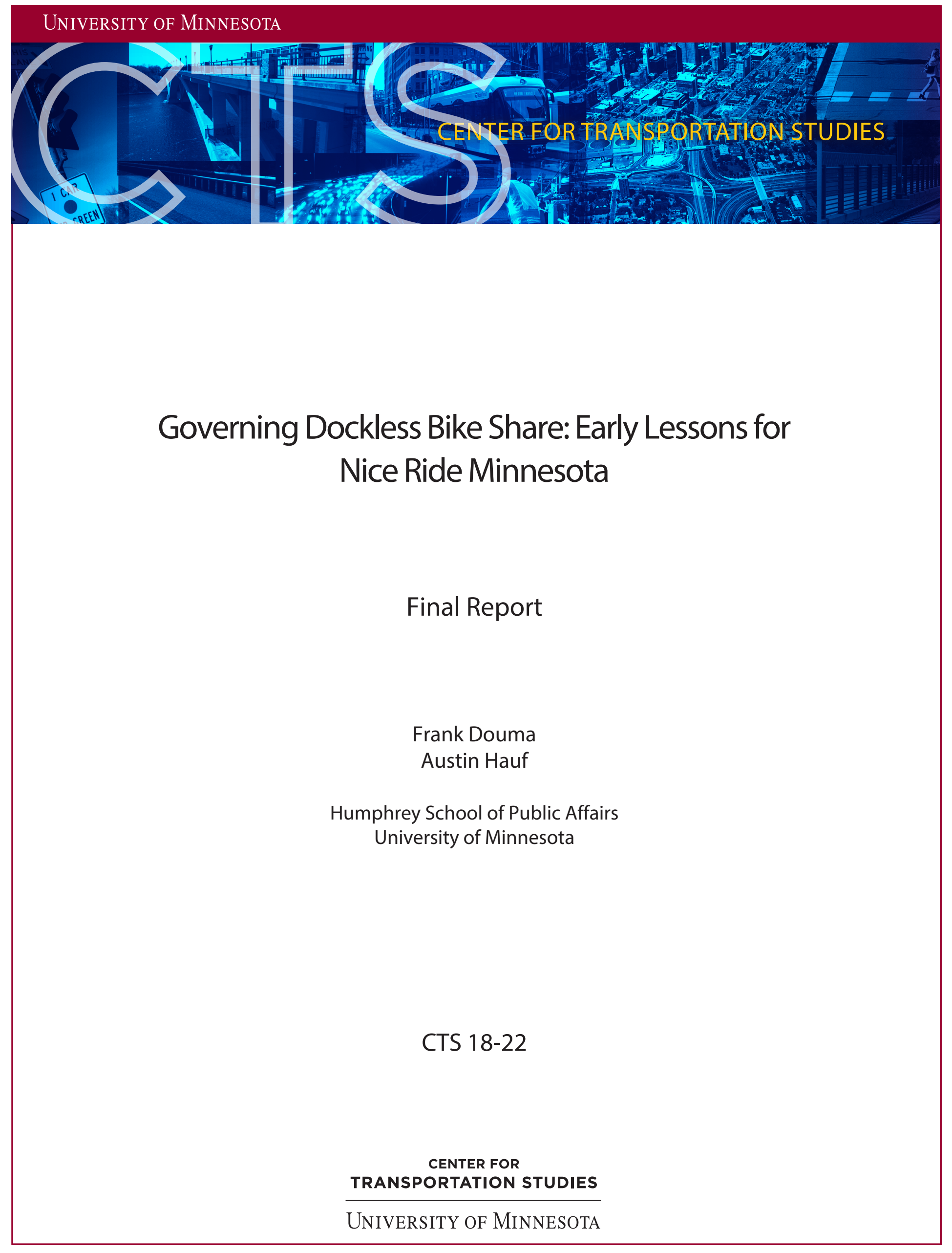


Technical Report Documentation Page

\begin{tabular}{|c|c|c|c|}
\hline $\begin{array}{l}\text { 1. Report No. } \\
\text { CTS } 18-22\end{array}$ & 2. & \multicolumn{2}{|c|}{ 3. Recipients Accession No. } \\
\hline \multirow{2}{*}{\multicolumn{2}{|c|}{$\begin{array}{l}\text { 4. Title and Subtitle } \\
\text { Governing Dockless Bike Share: Early Lessons for Nice Ride } \\
\text { Minnesota }\end{array}$}} & \multirow{2}{*}{\multicolumn{2}{|c|}{$\begin{array}{l}\text { 5. Report Date } \\
\text { November } 2018 \\
6 .\end{array}$}} \\
\hline & & & \\
\hline \multicolumn{2}{|c|}{$\begin{array}{l}\text { 7. Author(s) } \\
\text { Frank Douma and Austin Hauf }\end{array}$} & \multicolumn{2}{|c|}{ 8. Performing Organization Report No. } \\
\hline \multicolumn{2}{|c|}{$\begin{array}{l}\text { 9. Performing Organization Name and Address } \\
\text { Humphrey School of Public Affairs } \\
\text { University of Minnesota } \\
301 \text { 19th Avenue South } \\
\text { Minneapolis, MN } 55455\end{array}$} & \multicolumn{2}{|c|}{ 11. Contract (C) or Grant (G) No. } \\
\hline \multicolumn{2}{|c|}{$\begin{array}{l}\text { 12. Sponsoring Organization Name and Address } \\
\text { McKnight Foundation } \\
710 \text { South 2nd Street, Suite } 400 \\
\text { Minneapolis, MN } 55401\end{array}$} & \multicolumn{2}{|c|}{ 13. Type of Report and Period Covered } \\
\hline \multicolumn{4}{|c|}{$\begin{array}{l}\text { 15. Supplementary Notes } \\
\text { http://cts.umn.edu/publications/researchreports }\end{array}$} \\
\hline \multicolumn{4}{|c|}{$\begin{array}{l}\text { 16. Abstract (Limit: } 250 \text { words) } \\
\text { Dockless bike share systems present an opportunity for cities to expand access to bike share by lowering costs } \\
\text { and geographic barriers, but also create additional challenges in the areas of maintenance, parking, and right-of- } \\
\text { way management. Most dockless providers are also private, venture-capital funded entities, representing a } \\
\text { significant departure from current public and non-profit approaches. Other cities have encountered challenges in } \\
\text { securing cooperation from these operators in areas such as data transparency. This raises a key question: To what } \\
\text { extent can cities use contracts and governance to exchange use of the public right-of-way for operating } \\
\text { requirements that advance equity, accessibility, innovation, and other goals? Using case studies from other U.S. } \\
\text { cities and drawing insights from the wider "smart mobility" literature, this research presents recommendations } \\
\text { for regulating dockless bike share in cities and ties these approaches to the implementation of Nice Ride } \\
\text { Minnesota's dockless pilot. It will also examine prominent challenges in coordination and implementation and } \\
\text { highlight novel approaches with an eye towards the future of bike share in the Twin Cities. }\end{array}$} \\
\hline \multicolumn{2}{|c|}{$\begin{array}{l}\text { 17. Document Analysis/Descriptors } \\
\text { Vehicle sharing, Bicycling, Governance, City government, City } \\
\text { planning, Dockless bike sharing }\end{array}$} & \multicolumn{2}{|c|}{$\begin{array}{l}\text { 18. Availability Statement } \\
\text { No restrictions. Document available from: } \\
\text { National Technical Information Services, } \\
\text { Alexandria, Virginia } 22312\end{array}$} \\
\hline $\begin{array}{l}\text { 19. Security Class (this report) } \\
\text { Unclassified }\end{array}$ & $\begin{array}{l}\text { 20. Security Class (this page) } \\
\text { Unclassified }\end{array}$ & $\begin{array}{l}\text { 21. No. of Pages } \\
28\end{array}$ & 22. Price \\
\hline
\end{tabular}




\section{GOVERNING DOCKLESS BIKE SHARE: EARLY LESSONS FOR NICE RIDE MINNESOTA}

FINAL REPORT

Prepared by:

Frank Douma

Austin Hauf

Humphrey School of Public Affairs

University of Minnesota

\section{NOVEMBER 2018}

Published by:

Center for Transportation Studies

University of Minnesota

200 Transportation and Safety Building

511 Washington Ave. SE

Minneapolis, MN 55455

This report represents the results of research conducted by the authors and does not necessarily represent the views or policies of the McKnight Foundation and/or the University of Minnesota. This report does not contain a standard or specified technique.

The authors, the McKnight Foundation, and the University of Minnesota do not endorse products or manufacturers. Trade or manufacturers' names appear herein solely because they are considered essential to this report. 


\section{TABLE OF CONTENTS}

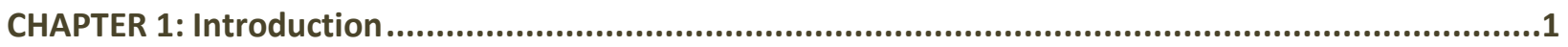

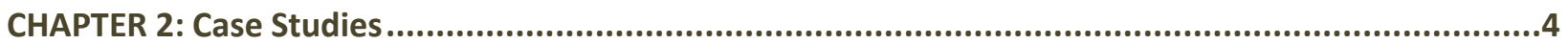

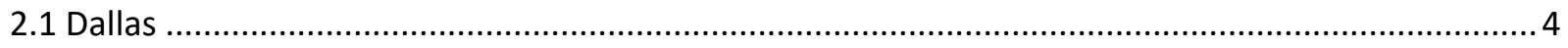

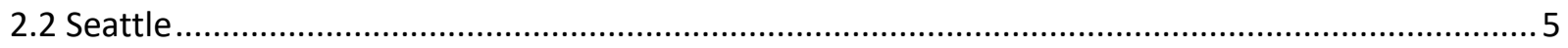

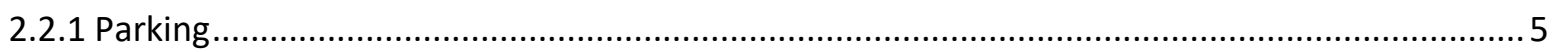

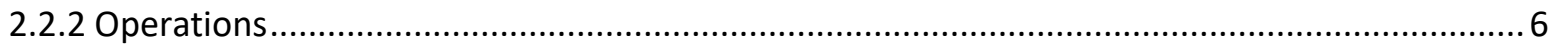

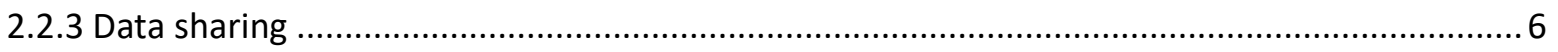

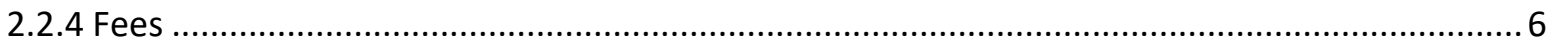

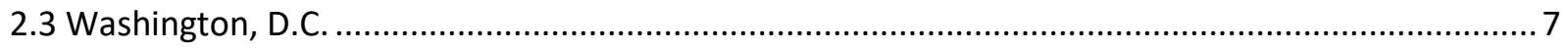

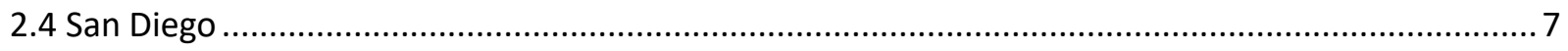

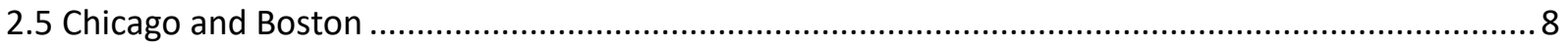

2.6 Major Challenges for Dockless Implementation and Governance ................................................ 9

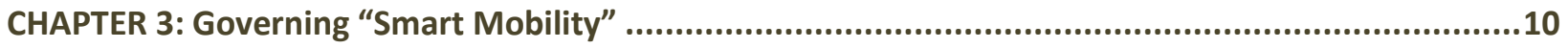

CHAPTER 4: Evaluating Nice Ride's Proposed Approach ............................................................12

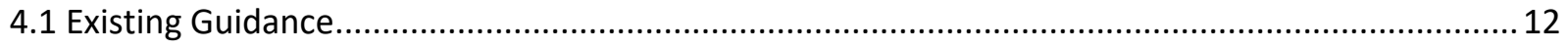

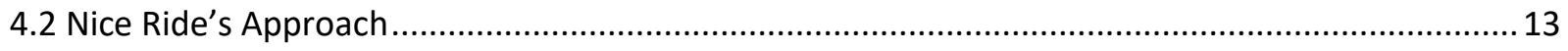

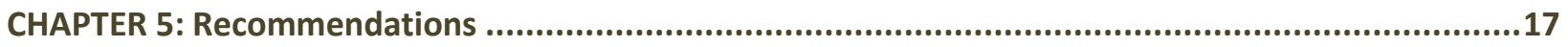

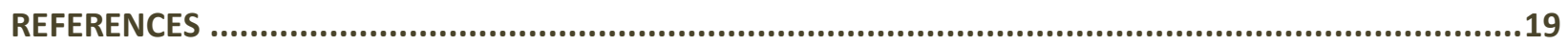

\section{LIST OF TABLES}

Table 4.1 : Comparison of Dockless Bike Share Governance Models and Regulations for Case Study Cities and Minneapolis/Nice Ride Minnesota 


\section{CHAPTER 1: INTRODUCTION}

Since 2010, Nice Ride Minnesota has operated a traditional dock-based bike share system based on a non-profit model and funded through a mix of public and private sources. Starting with only 65 stations and 700 bikes, the system has grown to 200 stations and 1,850 bikes and has provided millions of rides since its inception (Nice Ride Minnesota, 2018). While Nice Ride's 2010 launch made it one of the first major systems to debut in the United States (Institute for Transportation \& Development Policy, 2013, p. 148), the bike share market is currently experiencing significant disruption caused by the introduction of so-called "dockless" or "stationless" systems. Using bike-based GPS technology and built-in locks that immobilize the rear wheel, this approach allows users to start and end rides nearly anywhere using a smartphone app. By eliminating the need for docks these systems can reduce costs and deployment time, allowing them to serve a larger geographic area, charge less per ride, and eliminate the need for public funding (Institute for Transportation \& Development Policy, 2018). This is seen by some as an opportunity to make bike share more equitable. For example, a recently-launched dockless pilot on Chicago's south side is intended to provide cheaper rides in areas not fully served by Divvy, the city's docked system (Small, 2018). The dockless concept first emerged in Europe and China, and has only recently made its way to U.S. cities. In addition to fundamentally changing the physical footprint of bike share in cities, these systems are also primarily funded with venture capital, a major departure from the publicly-funded operations found in many U.S. cities (Institute for Transportation \& Development Policy, 2018). The combined influence of millions of cheap bikes and billions of dollars has changed the global landscape of bike share and altered many of the assumptions driving the operations of traditional docked systems like Nice Ride.

The decision to pursue a dockless transition was initiated both as a response to market conditions as well as a proactive attempt to evolve and innovate. As a technological evolution of the bike share concept, dockless has the potential to further the goals outlined in the Nonprofit Business Plan adopted by Nice Ride's Board of Directors by creating a more flexible system at a lower cost to users. Given the major changes taking place in the market, Nice Ride also anticipated significant future funding challenges. While system sponsors were willing to cover capital costs, ongoing funding for operations remained uncertain (Steve Sanders, personal communication, April 4, 2018). In the face of these challenges, Nice Ride also felt strongly about the need to continue operating the docked system through the extent of its expected life span to honor commitments from funders. With these considerations in 
mind, Nice Ride officially released its transition RFP in August of 2017, outlining five objectives for services delivered by a new contractual partner:

1. Operate and maintain our existing bike share system for its useful life.

2. Furnish and operate dockless bikes and enable customers to use both types of bikes seamlessly.

3. Meet civic goals for quality, reliability, and growth while working with right-of-way owners to manage introduction of new technology and thousands of new shared bikes.

4. Furnish related equipment, software, and services to meet civic goals for equity and innovation, and

5. Privately fund all of the above. (Nice Ride Minnesota, 2017, p. 2)

In late 2017, Nice Ride created an evaluation committee consisting of local bicycle advocates, academics, and public officials from the Twin Cities to evaluate applications (Nice Ride Minnesota, 2018, p. 8). The committee created and used a weighted scoresheet, which incorporated expanded versions of the objectives listed above, to narrow the field to two finalists, LimeBike and Motivate. Both companies were invited to publicly present their proposals at Macalester College in St. Paul. Motivate was awarded 87 percent of the possible points compared to LimeBike's 73 percent, and was scored higher by 12 out of 13 committee members resulting in a final recommendation that Motivate should move forward in the process (Nice Ride Minnesota, 2018, p. 8). Nice Ride board members concurred with this selection. In the updated 2018 business plan, Nice Ride outlines a few evaluation criteria that elevated Motivate over LimeBike:

- Will assure ability to continue existing service if dockless model fails (due to ROW conflicts, unsustainable business model, theft or any other reason)

- $\quad$ The contractor will manage on-street operations of both the existing system and the new system in a way that is reliable and efficient.

- $\quad$ The contractor has capacity (technology and staff) to maintain clear right of way for pedestrians, persons with disabilities, vehicles, etc.

- $\quad$ Customers will be able to use existing bikes and new bikes seamlessly.

- $\quad$ Reasonable terms for contract duration, branding, sponsorship, and service continuity assurances. (Nice Ride Minnesota, 2018, p. 8-9)

These distinguishing characteristics address some of the key concerns with dockless systems that will be discussed in more detail in a later section.

To this point, Nice Ride has served as a bike share provider for Minneapolis, St. Paul, and a handful of smaller right-of-way owners. During the transition process, Nice Ride attempted to establish a cooperative governance structure between Minneapolis, St. Paul, the Minneapolis Park Board, the University of Minnesota, and the National Park Service that would enable Motivate to cover this same geographic area, but complications ultimately resulted in the City of St. Paul removing itself from the process. The major issue that arose concerned the ability of Nice Ride to conduct an RFP for exclusive bike share rights on behalf of the City of St. Paul (Vezner, 2018). While the City of Minneapolis has a 
contract for services with Nice Ride, St. Paul's original contract had expired, and the City permitted stations to continue operating through other processes. Two distinct but related issues have made growing bike share ridership outside of downtown a challenge in St. Paul: A lack of bicycle infrastructure (especially compared to Minneapolis) and a relatively low station density. The combination of these two factors have left St. Paul relatively underserved by bike share in the past. Once St. Paul's city attorney had determined that the city could no longer move forward with the process, staff began holding discussions of a new RFP that would have included a joint powers agreement between the two cities. However, given monetary and time constraints, the City of Minneapolis and Nice Ride felt it was best to continue the existing process (Bill Dossett, personal communication, March 21, 2018). This led the City of St. Paul to begin drafting its own RFP for bike share services. While the separation of the two cities creates a short-term challenge for collaboration, the possibility remains open particularly if Motivate elects to respond to St. Paul's new RFP (Russ Stark, personal communication, April 9, 2018). In fact, the RFP presents the possibility of selecting up to two firms to provide services depending on a number of factors (City of St. Paul Department of Public Works, 2018, p. 3).

Before moving forward with the dockless transition, the City of Minneapolis pursued a formal bicycle sharing ordinance in consultation with local advocates and Nice Ride. The ordinance defines bike sharing broadly to include docked and dockless variants, establishes a requirement for operators to obtain a contract or license from the City, and allows the city to impound improperly parked bikes. It was adopted by the Minneapolis City Council on April 27, 2018 (City of Minneapolis, 2018). To understand the context in which this approach came about, we can take a closer look at the example of other cities currently hosting dockless systems. 


\section{CHAPTER 2: CASE STUDIES}

\subsection{DALLAS}

In August of 2017, the City of Dallas, Texas officially opened its doors to private bike share operators as part of a six-month pilot project. The City chose to allow vendors to begin operating with few limitations in order to evaluate issues as they arose and draft regulations in response. Five vendors now operate dockless systems in the area: VBikes, Spin, LimeBike, ofo, and Mobike. With an estimated 18,000 bikes in circulation, Dallas now boasts the largest bike share fleet in North America (Rogers, 2018, p. 4). According to documents presented to the City's Mobility Solutions, Infrastructure and Sustainability Committee on February 26th, 2018, roughly 70,000 Dallas residents have used LimeBike for over 183,000 rides. Twenty percent of all trips start or end near a transit station, and 51 percent of riders use the service during the evening rush hour (Rogers, 2018, p. 5). One source indicated that around 10,000 of the dockless bikes in use citywide are LimeBikes (McFarland, 2018). Data provided by ofo indicates that their bikes have been ridden a total of over 100,000 miles, with nearly 70 percent of trips starting or ending near a bus or rail stop (Rogers, 2018, p. 8). While these statistics are useful, the lack of consistent and reliable data for each system is just one of the city's major bike share challenges.

Despite the popularity of bike share in Dallas among riders, a number of issues continue to plague dockless operations. In September of 2017, the City updated its 311 reporting system to track comments related to bike share. At the time of the February 26th committee report, the system had received 1,401 comments involving all five vendors (Rogers, 2018, p. 11). These comments illustrate a number of issues that have also received heavy coverage from local and national press. First, dockless bikes are frequently vandalized or otherwise damaged. A report from February 9th suggested that of the 2,400 VBikes operating in the city, 600 were missing at the time of writing (Wilonsky, 2018b). Other vendors have not publicly reported similar losses, but photos of damaged bikes are a fixture in local news coverage and on social media. A popular Instagram account called "Dallas Bike Mess" (@dallasbikemess) has amassed over 8,700 followers and hosts almost 1,000 posts. A second issue concerns the impact of dockless bikes on public right of way. While the ability to lock bikes anywhere maximizes system mobility, it also leads to bikes left on curb ramps, in front of doorways, in the path of pedestrians on sidewalks, and in the middle of heavily-trafficked bike trails. This issue is made worse by a third issue that also prompted complaints to 311: That too many bikes have been allowed into the city at once (Rogers, 2018, p. 13). In response to these issues, the City held meetings and sent notices to bike share operators in an attempt to set higher expectations for ensuring that bikes are not blocking sidewalks, curb ramps, and trails, and threatened to move the bikes themselves if no action was taken. A February 9th deadline for cleanup came and went with little to no improvement (Wilonsky, 2018a). With ample experience and feedback from the pilot phase the City is now working on evaluation and policy development, but initial reports suggested that final recommendations would not be released until fall 2018 (Young, 2018). Transportation staff surprised the City Council's mobility committee in early April with a few proposed fee structures. Bike share companies with operations in Dallas joined Council members in criticizing the proposals, suggesting that they would push bike share out of the city (Wilonsky, 2018c). 
Policies under consideration include:

1. Bicycle parking standards, including parking areas for high-use zones and stricter guidelines for residential areas

2. Data sharing agreements, emphasizing the use of ridership data to help plan for bicycle routes and infrastructure

3. Safety standards and a requirement for bike share companies to play an active role in education and community engagement.

4. Developing metrics for the City to measure compliance

5. Creating franchise agreements, an application process, and a fee structure (Rogers \& White, 2018, p. 15-16)

\subsection{SEATTLE}

Dockless bike share is currently filling the void left by the failure of Pronto, Seattle's docked bike share system, which officially shut down on March 31, 2017 due to low ridership (Gutman, 2017). In June of the same year, the Seattle Department of Transportation (SDOT) introduced the country's first regulatory framework for issuing dockless bike share permits. SDOT granted one-year contracts to Spin, LimeBike, and ofo, allowing them to operate for the duration of a six-month pilot plus a subsequent six months while the city reviews the program's results (Lloyd, 2018). The permit requirements outlined by the city fall into five broad categories: Safety, parking, operations, data sharing, and fees (Seattle Department of Transportation, 2017). Several of these requirements are of particular note as potential responses to the issues seen in other cities with dockless bike share. These include:

\subsubsection{Parking}

- $\quad$ Bikes must be parked in the landscape/furniture zone of the sidewalk (area usually containing signs, streetlights, benches, etc.) or in one of SDOT's bike racks

- $\quad$ No parking in furniture zones of less than three feet

- $\quad$ No parking at sidewalk corners

- $\quad$ Bikes cannot block driveways, loading zones, curb ramps, bus stops, parklets, etc.

- $\quad$ Bikes can be parked on blocks with no sidewalks if they do not block travel lanes or the 6foot pedestrian zone

- $\quad$ SDOT has the right to implement geo-fenced stations

- $\quad$ Operators must remove incorrectly parked bikes within 2 hours of notice from 6am-6pm on non-holiday weeks, and within 10 hours of notice at all other times

- $\quad$ Operators can make arrangements with other property owners to establish parking zones in areas outside of City of Seattle right of way 
- $\quad$ Operators must provide 24-hour customer service by phone

- If deploying non-electric bikes, operators must maintain a minimum fleet size of 500 bikes

- $\quad$ Service areas should not exceed 340 bikes per square mile

- Operators with systems of 2,000+ bikes are required to include "Tier 1 Priority Hire" neighborhoods in 20 percent or more of their service area

\subsubsection{Data sharing}

- Operators must provide the City of Seattle with real-time data on bike location, ID number, type, and fuel level (For electric bikes), which the City is then permitted to publish to the public

- $\quad$ Operators must provide anonymized trip data to either the City of Seattle or the University of Washington Transportation Data Collaborative

- $\quad$ Operators must agree to allowing SDOT to hire a third-party researcher to assist with bike share program evaluation

\subsubsection{Fees}

- $\quad$ An annual permit to operate a bike share program costs $\$ 146$

- $\quad$ Stations or structures require additional permitting

- $\quad$ SDOT charges $\$ 209 /$ hour for permit review and inspection, which is estimated to take approximately eight hours

- Applicants will be charged an administrative fee of $\$ 15 /$ bike to cover administrative time during the bike share pilot (Seattle Department of Transportation, 2017)

While not all data has been publicly released, numbers from the first four months (July-October 2017) of the pilot speak to its popularity. With a combined fleet of 9,388 bikes, riders accumulated a total distance of 1,052,061 miles and averaged 2,711 trips per day. The average trip length was 3 miles, and the average trip duration was 30.3 minutes (Lloyd, 2018). Additional data released in December revealed a total of 347,300 trips in the pilot period up to that point (Corey \& Miller, 2017, p. 11). LimeBike's 2017 end of year report also provides some insight into how their share of the total fleet was utilized. With 39 percent of all rides taking place during the evening rush hour and 45 percent starting or ending near a public transit station, there is some evidence to suggest that the bikes are being used for commuting (LimeBike, 2017, p. 13).

The program has had its share of challenges as well. Despite detailed parking requirements, bikes are found blocking access to sidewalks, ADA ramps, transit, and businesses. Vandalism and broken bikes are a problem as well (Corey \& Miller, 2017, p. 13). In response to the parking issues, SDOT selected five locations to test the effectiveness of designated bike share parking areas. The $6^{\prime} \times 10^{\prime}$ painted rectangles 
follow current bike share parking guidelines and are located in areas of heavy bike share use. Staff will use pre- and post-installation parking compliance rates to measure the effectiveness of the designated parking zones (Mah, 2018). SDOT is currently conducting an evaluation of the six-month bike share pilot, and is expected to release recommendations for an ongoing program in spring 2018 (Corey \& Miller, 2017 , p. 18). The department released preliminary results of their analysis in a blog post, revealing that over 60,000 rides were recorded during the study period, geographic coverage was significantly wider than Pronto, and trips per bike per day averaged 0.84 (Seattle Department of Transportation, 2018).

\subsection{WASHINGTON, D.C.}

In September 2017, dockless bikes first began to augment Washington, D.C.'s successful Capital Bikeshare system as part of a seven-month pilot program. The District Department of Transportation (DDOT) granted permits to five operators: Spin, LimeBike, Jump, Mobike, and ofo (Ryan, 2017). During the pilot study period, operators could each deploy up to 400 bikes, were subject to parking requirements, and had to provide monthly data reports to DDOT (Eno Center for Transportation, 2018). The city has seen complaints similar to other cities about improperly parked bikes, as well as positive feedback from those who find the services useful (Capps, 2018). Over the study period, dockless providers reported 120,460 trips compared to Capital Bikeshare's 815,264 trips. Most trips began and ended within the same city ward, and trip starts clustered in the CBD and around Metro stations (Eno Center for Transportation, 2018). Equity is one of the program's major goals, and dockless operators are required to serve all wards. Available data suggest that while dockless bike usage was slightly higher than Capital Bikeshare usage in wards with high minority populations, it was still relatively low (Eno Center for Transportation, 2018). These results provide some refinement to previous anecdotal evidence about how dockless bike share providers are lowering barriers to biking for D.C.'s minority population (Sturdivant-Sani, 2018).

While many expected the unveiling of formal regulations after the conclusion of the pilot period, DDOT announced in late April that the program would continue with no changes. It was revealed that dockless operators had reacted poorly to proposed regulations that would have included tougher parking requirements and annual fees of up to $\$ 80,000$ for operators with the maximum allowed 400 bikes (Lazo, 2018). This mirrors the experience of transportation officials in Dallas, who faced similar industry opposition when they introduced a proposed fee structure. Additional data from upcoming summer operations may help chart a clearer path forward for regulation in D.C.

\subsection{SAN DIEGO}

San Diego officially joined the world of dockless bike share in early 2018 following the late January release of a key memo from the city attorney. The city signed a 10-year contract with DecoBike in 2013 to operate a traditional dock-based bike share system now known as DiscoverBike. Prior to the memo's release, it was unclear whether or not other bike share companies could legally operate in the city. Ultimately, the city attorney determined that while DecoBike's role as the city's "exclusive corporate 
partner as a bike sharing company" entitled them to city marketing and maintenance, the contract did not prevent them from allowing other providers to operate (Bowen, 2018a). Following this finding, the City of San Diego began issuing business tax certificates to bike share operators, and LimeBike officially launched on February 15th. In the first two weeks of operation, 21,000 new users had taken 55,000 rides in the city (Bowen \& Ruth, 2018). Other operators including ofo and Mobike soon followed. Two major issues have emerged since launch. In early March, the City began receiving complaints from local business groups detailing concerns over bikes left on sidewalks, possible liability issues, and a lack of engagement from the City in considering regulations (Garrick, 2018). They proposed banning the bikes until formal rules were established. The City refused to institute a ban, which prompted the Little Italy Association to begin relocating bikes parked in its commercial area to another street outside of the neighborhood (Bowen, 2018b). While some neighborhoods have rejected the bikes, others see them as a benefit to commercial activity and a source of mobility for low income residents. In the City Heights neighborhood, some see the new bikes filling a need that was not met by the existed docked system. The local business improvement district has even held events centered on using the bikes to patronize local shops and restaurants (Mento, 2018).

The second issue stems from the freedom to operate dockless bikes across city boundaries. While the cities of San Diego and Imperial Beach both allow dockless operations, nearby Coronado does not. When Coronado was approached by operators in December of 2017, it refused to issue them business permits under pressure from local bike rental companies (Solis, 2018a). After riders from the nearby cities started parking bikes in Coronado, the City responded by impounding the bikes and threatening operators with fines. LimeBike and Mobike are attempting to resolve the issue using "geofencing" technology, which allows them to designate the boundary of Coronado as a no parking zone, preventing users from ending their rides in prohibited areas (Solis, 2018b). San Diego's experience illustrates the importance of cooperation with both internal and external stakeholders for cities hoping for a smooth rollout of dockless bike share systems.

\subsection{CHICAGO AND BOSTON}

Two additional cases, both in their early stages, are also worth discussing briefly. As described in the background section, the City of Chicago recently began a dockless pilot in a pre-defined area on the city's south side, where Divvy has limited coverage (Small, 2018). This approach is being criticized by some who see the dockless bikes as a sub-standard replacement for Divvy stations (Wisniewski, 2018a). In addition to the pilot's focus on equity, it is also notable for instituting a requirement that all bikes in use after an initial trial period must be equipped with "lock-to" technology (City of Chicago, 2018). This means that instead of simply being immobilized with a wheel lock, they must be physically locked to a bike rack or other structure in a legal manner. The pilot currently includes a mix of compliant and noncompliant operators, and those not in compliance are hoping to change the city's mind before the July 1 deadline (Wisniewski, 2018b). The results of the pilot should be watched closely to evaluate the extent to which its equity goals are achieved, the outcome of the lock-to requirement, and the efficacy of using dockless providers to supplement an existing docked system. 
Boston's Metropolitan Area Planning Council (MAPC) is in the process of coordinating a summer 2018 rollout of a dockless pilot across 15 suburban communities. Boston, Cambridge, Somerville and Brookline will continue to be served exclusively by Hubway, Boston's docked system, but LimeBike and Spin will provide bikes for communities participating in the regional system (Harmon, 2018). MAPC's approach is unique in its attempt to reduce tension between municipalities (as seen in San Diego) by selecting specific vendors for a unified regional initiative. While coordination is being handled at the regional level, each city as well as other right-of-way owners (colleges, Massachusetts Bay Transportation Authority, etc.) will be allowed to institute their own regulations and permitting requirements, including parking, fees, winter operations, and more (Metropolitan Area Planning Council, 2017). The combination of cross-boundary standardization with allowances for locally-specific regulations provides one example of regional governance that should be evaluated post-launch to inform regional bike share collaboration in the Twin Cities.

\subsection{MAJOR CHALLENGES FOR DOCKLESS IMPLEMENTATION AND GOVERNANCE}

The case studies presented above touch on a few consistent challenges. Improperly parked bikes are a nearly universal problem in cities with dockless bike share, though the intensity of the problem is sometimes exaggerated. A December 2017 Portland Bureau of Transportation study conducted in Seattle found that 87 percent of dockless bikes observed were parked correctly (Orr, n.d., p. 9). However, only 44 percent of bikes had no observable maintenance issues, raising another common issue found in many cities (p. 8). Another study conducted in both Seattle and Washington, D.C. found that while 94 percent of bikes were parked upright, 12 percent had major defects and 8 percent were causing an obstruction of some kind (Bicycle Transit Systems, 2017, p. 1-2). Service fragmentation and "patchwork" regulations can be seen most clearly in San Diego, where systems face challenges to a complete network both within and beyond municipal boundaries. Dallas provides a cautionary tale about the importance of keeping systems scaled within reasonable demand. The experience of Washington, D.C. and Dallas illustrates the need to set realistic operating expectations, especially with regard to fees. The next section will draw on the smart mobility literature to build recommendations for how cities should approach the governance of shared mobility services such as dockless bike share. 


\section{CHAPTER 3: GOVERNING "SMART MOBILITY"}

Dockless bike share systems are one of a number of technologies known collectively as "smart mobility" which define what is known as the "smart mobility transition." This label serves as a catch-all term that encompasses autonomous vehicles (AVs), ride hailing services like Uber and Lyft (Also known as TNCs, or Transportation Network Companies), congestion-pricing schemes, Mobility as a Service (MaaS) platforms that aggregate transportation options, and other technology-driven transportation innovations. These technologies and services can also be described as part of the wider "sharing economy." Docherty, Marsden, and Anable (2017, p. 5-6) identify four characteristics associated with the smart mobility transition:

- $\quad$ A shift from ownership to usership, typified by on-demand ride-hailing services, car-sharing programs, and bike share systems

- A change in the definition of the mobility market, defined by the evolving allocation of tasks between the public and private sectors and the commodification of individual trips

- More convenient and comprehensive "inter-modality," defined by a shift from modalcentrism to user-centrism and the emergence of mobility aggregation services (MaaS)

- $\quad$ The evolving role of the citizen in the transportation system, as a provider of shared mobility services (Car-sharing) and as a data generator, driven by mobility platforms and smartphones

The smart mobility transition presents at least four major challenges to governments attempting to maintain public value as these forces shape the transportation system. The first considers the tradeoffs between the short-term gains from innovation and the long-term challenges of governance. Innovative service providers have an incentive to scale up, and absent effective governance in the period of transition it is unclear that the public sector will be able to impose requirements on providers once norms have been established (Docherty et al., 2017, p. 6-7). Dallas and Washington, D.C. have encountered this hurdle as they try to regulate bike share reactively rather than proactively. Providers currently operating in Dallas, for example, are attempting to hold down fees proposed by city transportation staff (Wilonsky, 2018c). The second challenge addresses taxes and the use of tax revenue (Docherty et al., 2017, p. 7). This conversation focuses primarily on infrastructure for cars, but it provides a reminder of the need for local governments to maintain an influence on pricing and fees for transportation services. The third challenge deals with information and data. Smart mobility is complicating both the generation and ownership of travel data, a key source of information for transportation planning and decision making (Docherty et al., 2017, p. 8). The proliferation of private transportation providers across modes has put some data out of reach (Bliss, 2018), pushing cities like Seattle and Washington, D.C. to include data-sharing provisions in bike share permit agreements (Seattle Department of Transportation, 2017). Finally, a fourth challenge illustrates concerns over business models and equity (Docherty et al., 2017, p. 8-9). It is still unclear whether private mobility providers will ultimately complement public transit providers or reduce their ridership through competition. Preliminary data from Washington, D.C. also questions the extent to which dockless bike share is serving minority residents (Eno Center for Transportation, 2018). Without a clear strategy for 
ensuring equitable access to private mobility services, cities will miss an opportunity to advance existing planning goals during the period of transition for both car and bike sharing.

The smart mobility literature has identified a major mismatch between cities' stated planning goals and current policy approaches to regulating new technologies and services. Davis (2018) examines the process by which Uber first entered the transportation market in San Francisco by using a "tactically incremental approach," ultimately securing permission to operate legally. This approach allowed Uber to dictate the terms of policy development, emboldened by a mayor who pushed for regulatory changes on the grounds of supporting innovation rather than enhanced mobility (Davis, 2018, p. 116). Similarly, in assessing the extent of AV policy across U.S. metro areas, Freemark and Zhao (2018) found a strong preference for promoting innovation over planning goals such as equity, sustainability, efficiency, and livability, even when these goals were explicitly outlined in transportation plans. In light of the challenges outlined above, cities may be missing a key opportunity to establish more robust governance frameworks that guarantee public value in the face of a rapidly evolving transportation landscape. Through an updated Grant Funded Agreement with Nice Ride, the City of Minneapolis has the opportunity to support an existing partner who can effectively monitor the dockless system and advance mutual priorities. 


\section{CHAPTER 4: EVALUATING NICE RIDE'S PROPOSED APPROACH}

\subsection{EXISTING GUIDANCE}

While the dockless bike share space is still largely defined by experimentation, some efforts have been made to identify best practices. In January of 2018, the North American Bikeshare Association (NABSA) released a set of preliminary guidelines to assist local government entities on issues such as the RFP process, service area, fleet size, parking, safety, equity, insurance, open data, and evaluation (2018a). While this report identifies some concrete recommendations, it leaves many of the details up to local discretion. NABSA does not provide licensing or other endorsements of specific operators, however there is some evidence that cities are beginning to look to the organization for guidance. Recent dockless proposals in Chicago (City of Chicago, 2018) and Reno (City of Reno, 2018) have required applicants to be NABSA members in good standing (Or members of a similar organization, in Chicago's case). Ofo, the only major bike share operator to run afoul of the organization, was expelled for breaking the code of conduct by lobbying for a Florida bill that would have preempted municipal control over the implementation of bike share programs (North American Bikeshare Association, 2018b). An analysis of current regulatory best practices prepared in advance of Chicago's dockless bike share pilot provides further weight to many of these recommendations and compares regulations across multiple cities. The authors present findings in four categories: (1) Operations \& Maintenance, (2) Ethical Standards, (3) Fleet Number, Rebalancing \& Parking Requirements, and (4) Safety (Bordenkircher \& O'Neil, 2018, p. 2). While this provides an interesting comparison of differing approaches to specific rules, it provides little in the way of overall guidance for governance.

The Institute for Transportation \& Development Policy proposes a higher-level policy framework for dockless bike share to promote fairness and efficiency for operators, provide high quality service for users, and set a baseline for evaluating success (Yanocha, 2018, p. 6). Echoing guidance from the smart mobility literature, the framework suggests explicitly positioning bike share services within a city's goals related to transportation planning, health, safety, multi-modality, or other priorities (p. 8). Four "operations level objectives" are proposed to meet these goals: Effectively manage public space, foster equity \& accessibility, improve planning \& enforcement, and protect users. The framework also includes an evaluation component that encourages cities to pursue policy enforcement through real-time data access and verification, and suggests using the results alongside user feedback to drive the evolution of policy and the adoption of new technologies and business models (p. 7).

The wider literature on smart mobility and AVs sheds additional light on the role of cities as regulators and the need for regional collaboration. Glancy (2015) notes that transportation issues relevant to AVs such as parking and speed limits are determined by local ordinances (p. 649-650). Freemark and Zhao (2018) argue that since municipal governments exercise their police powers to act as regulators of public right-of-way, they should be key players in the deployment of smart mobility technologies such as AVs (p. 7). While cities should take the lead in determining their own policies, regional consistency is an important consideration for shared mobility services (Ory, Slowik, \& Kamakate, 2017, p. 4; National League of Cities, 2017, p. 6). The above case study from San Diego illustrates the need for stronger 
regional collaboration in dockless bike share. A recently announced effort for 15 Boston suburbs coordinated by the region's Metropolitan Area Planning Council provides one potential approach, and should be watched closely (Harmon, 2018). One potential threat to local and regional efforts comes in the form of future state-level bike share preemption legislation, which was defeated in both Florida and Oklahoma in 2018 (Bossert, 2018).

\subsection{NICE RIDE'S APPROACH}

Nice Ride's approach to dockless bike share is fundamentally different in structure and strategy from what other cities have pursued. The existing research on dock-based bike share points to a need for cities and systems to articulate a clear purpose and define their own metrics for success (de Chardon, Caruso, \& Thomas, 2017), and the legacy relationship between the City of Minneapolis and Nice Ride that facilitates the operation of the current docked system provides a framework of shared goals that continue to guide dockless bike share planning and implementation. The original 2008 business plan had three core goals:

1. Establishing bike sharing as a convenient and reliable form of transportation

2. Increasing bicycle mode share

3. Increasing cultural acceptance of active transportation (Nice Ride Minnesota, 2018, p. 2)

Nice Ride's intentional and objective-driven approach to dockless bike share has the potential to avoid some of the challenges encountered in other cities. The 2018 business plan update outlines five strategies that define Nice Ride's approach to dockless bike sharing, and suggest an approach to bike share focused on goals over pure innovation:

1. Contracting for transparency and innovation

2. Using "virtual station" technology to create orderly, designated dockless bike parking areas

3. Equitable service

4. Robust data sharing

5. Prioritize quality and reliability over growth (Nice Ride Minnesota, 2018, p. 2)

Strategy one sets the expectations for a clearly defined relationship between the City of Minneapolis as the primary right-of-way owner, the Nice Ride Board as the contract oversight body, and Motivate as the owner/operator of the system itself. Strategy two is a reasonable response to the challenge of "bike clutter" faced by other cities piloting dockless bike share, and will hopefully minimize backlash. Strategy three is key to furthering Nice Ride's goals, and current plans are more ambitious than those put forth in other case study cities. Dockless systems are currently reaching cities and neighborhoods that are traditionally underserved by bike share, but success in these areas is still uncertain (Schmitt, 2018b). Strategy four will enable Nice Ride's current level of data sharing to continue, and will set a precedent 
for dockless systems in the Twin Cities. Finally, strategy five truly sets Nice Ride apart from other dockless systems by making an explicit commitment to quality and reliability, echoing the system's original goals. Motivate is a well-established provider of bike share equipment, and should help Nice Ride avoid the problems encountered elsewhere with customers seeing the bikes as disposable. Table 1 provides a high-level comparison of current governance models and key challenges for case study cities and Nice Ride, with criteria drawn from the sources of existing guidance described above. 
Table 4.1 : Comparison of Dockless Bike Share Governance Models and Regulations for Case Study Cities and Minneapolis/Nice Ride Minnesota

Dallas Seattle

Washington, D.C.

San Diego

Minneapolis (Nice Ride)

\begin{tabular}{|c|c|c|c|c|c|}
\hline Status & Regulations forthcoming & $\begin{array}{l}\text { Analyzing pilot data, } \\
\text { regulations } \\
\text { forthcoming }\end{array}$ & $\begin{array}{l}\text { Analyzing pilot data, } \\
\text { regulations forthcoming }\end{array}$ & N/A & $\begin{array}{l}\text { Planning, launch expected } \\
\text { summer } 2018\end{array}$ \\
\hline Governance Model & Ad-hoc & $\begin{array}{l}\text { Official pilot, city } \\
\text { issues permits to } \\
\text { operators }\end{array}$ & $\begin{array}{l}\text { Official pilot, city issues } \\
\text { permits to operators }\end{array}$ & $\begin{array}{l}\text { Ad-hoc, operators } \\
\text { nominally subject to } \\
\text { local business } \\
\text { regulations }\end{array}$ & $\begin{array}{l}\text { City provides exclusivity, Nice } \\
\text { Ride provides contract oversight, } \\
\text { Motivate owns/operates system }\end{array}$ \\
\hline \multicolumn{6}{|l|}{ Key Challenges } \\
\hline Right-of-Way Management $^{1}$ & $\begin{array}{l}\text { No official regulations, } \\
\text { policy under } \\
\text { consideration }\end{array}$ & $\begin{array}{l}\text { Parking requirements, } \\
\text { designated parking } \\
\text { area pilot }\end{array}$ & $\begin{array}{l}\text { City issues public right-of- } \\
\text { way occupancy permit, } \\
\text { parking requirements }\end{array}$ & $\begin{array}{l}\text { Operators nominally } \\
\text { subject to local } \\
\text { business regulations }\end{array}$ & $\begin{array}{l}\text { Site-planned "virtual stations" } \\
\text { subject to city approval }\end{array}$ \\
\hline Data Availability² & $\begin{array}{l}\text { No official regulations, } \\
\text { policy under } \\
\text { consideration }\end{array}$ & $\begin{array}{l}\text { Data must be } \\
\text { provided to city or } \\
\text { University of } \\
\text { Washington } \\
\text { Transportation Data } \\
\text { Collaborative }\end{array}$ & $\begin{array}{l}\text { Monthly data reporting } \\
\text { requirement }\end{array}$ & No official regulations & $\begin{array}{c}\text { Motivate must provide Nice Ride } \\
\text { and City with real-time and } \\
\text { aggregated data }\end{array}$ \\
\hline
\end{tabular}

${ }^{1}$ Institute for Transportation \& Development Policy, 2018; North American Bikeshare Association, 2018a; Yanocha, 2018; Bordenkircher \& O’Neil, 2018

${ }^{2}$ Ibid. 


\begin{tabular}{|c|c|c|c|c|c|}
\hline Equity 3 & No official regulations & $\begin{array}{l}\text { Systems with } 2,000+ \\
\text { bikes must serve } \\
\text { economically } \\
\text { distressed } \\
\text { neighborhoods }\end{array}$ & $\begin{array}{l}\text { Systems must operate in all } \\
\text { city wards }\end{array}$ & No official regulations & $\begin{array}{c}\text { Bike redistribution, discounted } \\
\text { memberships, non-smart } \\
\text { phone/unbanked options }\end{array}$ \\
\hline Safety ${ }^{4}$ & No official regulations & $\begin{array}{l}\text { Bikes must meet state } \\
\text { and federal safety } \\
\text { standards }\end{array}$ & $\begin{array}{l}\text { Bikes must meet state and } \\
\text { federal safety standards }\end{array}$ & $\begin{array}{l}\text { Operators nominally } \\
\text { subject to local } \\
\text { business regulations }\end{array}$ & $\begin{array}{l}\text { Bikes must meet state and } \\
\text { federal safety standards }\end{array}$ \\
\hline Regional Coordination ${ }^{5}$ & $\mathrm{~N} / \mathrm{A}$ & $\mathrm{N} / \mathrm{A}$ & N/A & $\begin{array}{l}\text { Lack of coordination } \\
\text { resulted in dockless } \\
\text { bike ban in } \\
\text { neighboring City of } \\
\text { Coronado }\end{array}$ & $\begin{array}{l}\text { Unsuccessful coordination with } \\
\text { St. Paul, still possible through } \\
\text { Motivate response to St. Paul } \\
\text { RFP }\end{array}$ \\
\hline System Sustainability ${ }^{6}$ & $\begin{array}{l}\text { Venture capital funding, } \\
\text { uncertain }\end{array}$ & $\begin{array}{l}\text { Venture capital } \\
\text { funding, uncertain }\end{array}$ & $\begin{array}{l}\text { Venture capital funding, } \\
\text { uncertain }\end{array}$ & $\begin{array}{l}\text { Venture capital } \\
\text { funding, uncertain }\end{array}$ & $\begin{array}{l}\text { Motivate must continue to } \\
\text { operate docked system if } \\
\text { dockless pilot unsuccessful }\end{array}$ \\
\hline
\end{tabular}

3 Ibid.

${ }^{4}$ North American Bikeshare Association, 2018a; Yanocha, 2018; Bordenkircher \& O'Neil, 2018

${ }^{5}$ Ory, Slowik, \& Kamakate, 2017; National League of Cities, 2017; Freemark \& Zhao, 2018

${ }^{6}$ Institute for Transportation \& Development Policy, 2018; Docherty et al., 2017; Yanocha, 2018 


\section{CHAPTER 5: RECOMMENDATIONS}

While the rapidly-evolving nature of dockless bike share regulation makes it difficult to establish firm criteria for evaluating governance models, lessons learned from case studies and the smart mobility literature allow us to make some general observations and recommendations for cities and service providers.

1. Cities should proactively and transparently regulate smart mobility services that operate on their right-of-way. Reactionary regulations are missed opportunities for cities to define a regulatory environment that could advance their goals, as was the case with Uber in San Francisco, described above.

2. Service providers should expect to make concessions in exchange for use of right-of-way. Providing access to usage data is just one example of a reasonable expectation for cities to place on smart mobility service providers. In light of privacy concerns, one promising model is the use of a third-party data-sharing entity such as the National Association of City Transportation Official (NACTO)'s SharedStreets, which successfully partnered with Uber (Marshall, 2018), or the University of Washington's Transportation Data Collaborative, which is currently analyzing Seattle's dockless permit data.

3. Cities should continue to place goals in the areas of transportation planning, health, safety, etc. above innovation. Nice Ride's contract oversight model should help its board and the City hold Motivate accountable for advancing their original goals through the new strategies outlined for the dockless pilot. Nice Ride and the City of Minneapolis have articulated a strong set of goals and values that are driving innovation.

4. Cities and operators should maintain an environment and expectation for iteration. Given the rapid change that has taken place in bike share markets and technology, cities and operators should expect flexibility in governance models and contracts. For example, Seattle's permit requirements lay out initial parking regulations, but also give the City the right to create "geo-fenced" stations in the future where bikes in certain areas must be parked (Seattle Department of Transportation, 2017). Nice Ride's revised business plan provides a list of assurances that speak to a similar level of flexibility in implementation (Nice Ride Minnesota, 2018, p. 12-14). Flexibility at the municipal level is especially important given that dockless bikes are not the only disruptive personal mobility devices being rapidly deployed in U.S. cities. As electric scooter-sharing systems start to proliferate, cities at the forefront are developing governance frameworks that can apply or be adapted to multiple modes (Benner, 2018).

5. Cities need to define what success looks like. Cities that implement bike sharing systems do so for a variety of reasons (sometimes poorly defined), but researchers tend to use a single metric, trips per day per bike (TDB), to compare them (de Chardon, Caruso, \& Thomas, 
2017). One of dockless bike share's stated benefits is the ability to cover a wider geographic area, an aspect of system design that could have a major impact on this metric. A recent NACTO report found that while approximately 44 percent of the current U.S. bike share fleet are dockless, they accounted for only 4 percent of total bike share trips (2018). Making the comparison to well-established docked systems is problematic for a variety of reasons, but dockless systems still received negative press as a result (Vock, 2018; Schmitt, 2018a). This provides another reminder of the need for cities to clearly articulate measurable goals if they hope to avoid this type of criticism.

\section{Nice Ride should increase its efforts to collaborate within and beyond municipal}

boundaries. The San Diego case study above provides a useful reminder of the need for collaboration in transportation networks. While Nice Ride and the City of Minneapolis are taking a much more proactive approach in setting expectations for neighborhoods and business owners, other cities need to be engaged in discussions about what the future of bike share looks like in the Twin Cities. Reengagement with St. Paul should be a key goal, but representatives from nearby communities who are at various stages of dockless bike share interest and deployment, such as Golden Valley, St. Louis Park, and Edina, should also be at the table (Marc Nevinski, personal communication, April 4, 2018). As noted above, the results of regional approaches like the one planned in the Boston region could be a source of insight. The existing Twin Cities Shared Mobility Action Plan (Shared-Use Mobility Center, 2017) and an emerging regional Shared Mobility Collaborative led by MnDOT and Metro Transit (Isaacson \& Levin, 2018) should also help guide local policy and cooperation. 


\section{REFERENCES}

Benner, R. (2018). Ding, ding! Round one of dockless scooters. Transportation for America Blog. Retrieved from http://t4america.org/2018/05/14/ding-ding-round-one-dockless-scooters

Bicycle Transit Systems. (2017). Summary of field review of dockless bike share. Retrieved from http://usa.streetsblog.org/wp-content/uploads/sites/5/2018/02/Bike-Transit-Dockless-bike-shareresearch-memo-120417.pdf

Bliss, L. (2018, Jan 12). To measure the 'Uber effect,' cities get creative. CityLab. Retrieved from https://www.citylab.com/transportation/2018/01/to-measure-the-uber-effect-cities-getcreative/550295

Bordenkircher, B. \& O'Neil, R.L. (2018). Dockless bikes: Regulation breakdown. Twelve Tone Consulting. Retrieved from http://chi.streetsblog.org/wp-content/uploads/sites/4/2018/04/Dockless-BikeRegulation-Breakdown.pdf

Bossert, H. (2018). North American Bikeshare Association triumphs over harmful Oklahoma bikeshare bill. North American Bikeshare Association. Retrieved from https://nabsa.net/2018/05/01/northamerican-bikeshare-association-triumphs-harmful-oklahoma-bikeshare-bill

Bowen, A. (2018a, Jan 24). San Diego city attorney memo opens door to 'dockless' bike sharing. KPBS. Retrieved from http://www.kpbs.org/news/2018/jan/24/san-diego-city-attorney-memo-opens-doordockless-b

Bowen, A. (2018b, Mar 27). Little Italy Association is evicting dockless bike sharing. KPBS. Retrieved from http://www.kpbs.org/news/2018/mar/27/little-italy-association-dockless-bike-sharing

Bowen, A. \& Ruth, B. (2018, Mar 22). How San Diego is responding to the dockless bike craze. KPBS. Retrieved from http://www.kpbs.org/news/2018/mar/22/how-san-diego-responding-dockless-bikecraze

Capps, K. (2018, Jan 19). What people mean when they call dockless bikeshare a 'nuisance.' CityLab. Retrieved from https://www.citylab.com/transportation/2018/01/what-people-mean-when-they-calldockless-bike-share-a-nuisance/550253/

City of Chicago. (2018). City of Chicago permit requirements - for dockless bikeshare vendors only. Retrieved from https://www.cityofchicago.org/content/dam/city/depts/cdot/bike/general/Chicago_DoBi_Pilot_Progra m_04.24.18.pdf

City of Minneapolis. (2018). Ordinance no. 2018-015. Retrieved from https://lims.minneapolismn.gov/Download/MetaData/7227/2018-00314\%200rd\%20015_Id_7227.pdf 
City of Reno. (2018). Request for qualifications \#030091: Dockless no cost bikeshare equipment and operations. Retrieved from https://nabsa.net/wp-content/uploads/2017/09/Reno-Dockless-RFQ.pdf

City of St. Paul Department of Public Works. (2018). Request for proposal event \#649 for a bicycle sharing program. Retrieved from

https://www.stpaulbids.com/Imp/SourcingSupplier/Im?_In=AllEvents\&_r=3\&bto=SourcingEvent\&dataar ea=Imp\&name=Summary\&service=form\&webappname=SourcingSupplier\&Company=1\&SourcingEvent= $649 \#$

Corey, E. \& Miller, J. (2017). 2017 Bike share pilot: Regulatory framework for free-floating bike share [PowerPoint slides]. Retrieved from https://1p40p3gwj70rhpc423s8rzjaz-wpengine.netdna-ssl.com/wpcontent/uploads/2017/12/2017.12.13-SPAB_Dec2017-Bike_share_Dec11.pdf

Davis, D.E. (2018). Governmental capacity and the smart mobility transition. In G. Marsden and L. Reardon (Eds.), Governance of the smart mobility transition (pp. 105-122). Bingley, UK: Emerald. de Chardon, C.M., Caruso, G., \& Thomas, I. (2017). Bicycle sharing system 'success' determinants. Transportation Research Part A: Policy and Practice, 100, 202-214.

https://doi.org/10.1016/j.tra.2017.04.020

Docherty, I., Marsden, G., \& Anable, J. (2017). The governance of smart mobility. Transportation Research Part A, 2017, 1-12. http://dx.doi.org/10.1016/j.tra.2017.09.012

Eno Center for Transportation. (Producer). (2018). The latest on DC's dockless bike sharing pilot [Video webinar]. Retrieved from https://www.enotrans.org/events/results-from-dcs-dockless-bikesharing-pilot Freemark, Y. \& Zhao, J. (2018). An urban agenda for autonomous vehicles: Embedding planning principles into technological deployment. Paper presented at Transportation Research Board 97th Annual Meeting, Washington, D.C.

Garrick, D. (2018, Mar 8). Frustrated merchants want temporary dockless bike ban so San Diego can create rules. The San Diego Union-Tribune. Retrieved from http://www.sandiegouniontribune.com/news/transportation/sd-me-bikes-merchants-20180308story.html

Glancy, D. J. (2015). Autonomous and automated and connected cars--oh my! First generation autonomous cars in the legal ecosystem. Minnesota Journal of Law, Science and Technology, 16(2), 619691.

Gutman, D. (2017, Mar 28). Seattle's Pronto bike share shut down on March 31. The Seattle Times. Retrieved from https://www.seattletimes.com/seattle-news/transportation/seattle-pronto-bike-shareshutting-down-friday 
Harmon, E. (2018). MAPC selects LimeBike, Spin for 15-community regional bike share system. Metropolitan Area Planning Council. Retrieved from https://www.mapc.org/news/mapc-selectslimebike-spin-for-15-community-regional-bike-share-system

Institute for Transportation \& Development Policy (ITDP). (2013). The bike-share planning guide. Retrieved from https://www.itdp.org/the-bike-share-planning-guide-2

Institute for Transportation \& Development Policy (ITDP). (2018). Dockless bikeshare: What we know so far. Retrieved from https://www.itdp.org/dockless-bikeshare-know-so-far

Isaacson, B., \& Levin, J. (2018). Shared mobility update [PowerPoint slides]. Retrieved from https://minnesota.uli.org/wp-content/uploads/sites/31/2018/05/Brian-Isaacson-and-John-LevinShared-Mobility-Update.pdf

Lazo, L. (2018, Apr 28). D.C. withdraws plan targeting dockless bike operations with fees and parking demands. The Washington Post. Retrieved from https://www.washingtonpost.com/local/trafficandcommuting/dc-withdraws-plan-targeting-docklessbike-operations-with-fees-and-parkingdemands/2018/04/28/2d89c64e-48ca-11e8-827e190efaf1f1ee_story.html?utm_term=.d0bb8a2d1922

LimeBike. (2017). LimeBike: The year end report. Retrieved from https://www.limebike.com/hubfs/EOY\%20Data\%20Report.pdf

Lloyd, S.A. (2018, Jan 8). What's next for the city's bike-share pilot? Curbed Seattle. Retrieved from https://seattle.curbed.com/2018/1/8/16864966/seattle-dockless-bike-share-pilot

Mah, N. (2018). New in Ballard | Designated bike share parking areas. SDOT Blog. Retrieved from http://sdotblog.seattle.gov/2018/03/15/new-designated-bike-share-parking-areas-come-to-ballard

Marshall, A. (2018, Apr 16). Uber makes peace with cities by spilling its secrets. Wired. Retrieved from https://www.wired.com/story/uber-nacto-data-sharing/?utm_source=citylab-

daily\&silverid=NDQ3MzgzMTcxNDc4SO

McFarland, M. (2018, Feb 5). Dallas's rush into bikeshare turns controversial. CNN Tech. Retrieved from http://money.cnn.com/2018/02/05/technology/dallas-bikeshare-limebike-ofo/index.html

Mento, T. (2018, Apr 4). City Heights embraces dockless bikes while other communities fight them. KPBS. Retrieved from http://www.kpbs.org/news/2018/apr/04/city-heights-embraces-dockless-bikeswhile-other-c

Metropolitan Area Planning Council. (2017). No cost bike sharing system: Request for proposals. Retrieved from http://www.mapc.org/wp-content/uploads/2017/12/MAPC-2018-No-Cost-Bike-ShareRFP_FINAL_121117_clean.pdf

National Association of City Transportation Officials (NACTO). (2018). Bike share in the U.S.: 2017. Retrieved from https://nacto.org/wp-content/uploads/2018/05/NACTO-Bike-Share-2017.pdf 
National League of Cities. (2017). Autonomous vehicles: A policy preparation guide. Retrieved from http://www.nlc.org/sites/default/files/2017-04/NLC\%20AV\%20Policy\%20Prep\%20Guide\%20web.pdf

Nice Ride Minnesota. (2017). Request for proposals for transition of Twin Cities bike sharing system. Retrieved from https://www.niceridemn.org/_asset/s3v7hr/RFP-for-Transition-of-the-Twin-Cities-BikeShare-System---FINAL.pdf

Nice Ride Minnesota. (2018). 2018 Update to nonprofit business plan. Retrieved from https://www.niceridemn.org/_asset/rmh8ek/Revised-NRM-Business-Plan-Update.pdf

North American Bikeshare Association (NABSA). (2018a). Dockless bikeshare regulation preliminary guidance. Retrieved from https://nabsa.net/wp-content/uploads/2017/09/Dockless-RegulationPreliminary-Guidance-1.pdf

North American Bikeshare Association (NABSA). (2018b). NABSA expels ofo US Limited for code of conduct violation. Retrieved from https://nabsa.net/2018/03/22/nabsa-expels-ofo-us-limited-codeconduct-violation

Orr, B. (n.d.). Dockless bikeshare: Observations from Seattle. Portland Bureau of Transportation. Retrieved from https://nabsa.net/wp-content/uploads/2017/09/Seattle-DocklessObservations_Portland_R2.pdf

Ory, D., Slowik, P., \& Kamakate, F. (2017). Governance: Who's in charge here? (Policy Brief). UC Davis Institute of Transportation Studies. Retrieved from https://3rev.ucdavis.edu/wpcontent/uploads/2017/03/3R.Governance.Indesign.Final_.pdf

Rogers, M., \& White, J. (2018). Bike share program update [PowerPoint slides]. Retrieved from http://dallascityhall.com/government/Council\%20Meeting\%20Documents/msis_3_bike-share-programupdate_combined_022618.pdf

Ryan, K. (2017, Dec 8). How dockless bikes stack up against Capital Bikeshare in DC. WTOP. Retrieved from https://wtop.com/dc/2017/12/dock-less-bikes-stack-capital-bikeshare-dc/slide/1

Schmitt, A. (2018a, May 2). Trip data deflates the dockless bike-share hype. Streetsblog USA. Retrieved from https://usa.streetsblog.org/2018/05/02/trip-data-deflates-the-dockless-bike-share-hype

Schmitt, A. (2018b, May 10). Dockless companies deliver bike-share to underserved areas. Streetsblog USA. Retrieved from https://usa.streetsblog.org/2018/05/10/dockless-companies-delivering-bike-shareto-underserved-areas

Seattle Department of Transportation. (2017). Bike share permit requirements. Retrieved from http://www.seattle.gov/Documents/Departments/SDOT/BikeProgram/BicycleSharePermitRequirements .pdf

Seattle Department of Transportation. (2018). Bike share | Survey's juicy details! SDOT Blog. Retrieved from http://sdotblog.seattle.gov/2018/05/02/bike-share-by-the-numbers 
Shared-Use Mobility Center. (2017). Twin Cities shared mobility action plan. Retrieved from http://sharedusemobilitycenter.org/wp-content/uploads/2017/10/SUMC_TWINCITIES_Web_Final.pdf

Small, A. (2018, May 10). Chicago's south side gets dockless bikeshare. CityLab. Retrieved from https://www.citylab.com/transportation/2018/05/chicagos-south-side-gets-dockless-bike-share/560042

Solis, G. (2018a, Mar 20). Coronado to impound dockless bikes, fine companies. The San Diego UnionTribune. Retrieved from http://www.sandiegouniontribune.com/communities/south-county/sd-secoronado-dockless-20180319-story.html

Solis, G. (2018b, Mar 29). Coronado impounds 26 dockless bikes, companies build virtual fence around the island. The San Diego Union-Tribune. Retrieved from http://www.sandiegouniontribune.com/communities/south-county/sd-se-coronado-folo-20180329story.html

Sturdivant-Sani, C. (2018, Jan 9). Can dockless bikeshare pump up cycling's diversity? CityLab. Retrieved from https://www.citylab.com/transportation/2018/01/can-dockless-bikeshare-pump-up-cyclingsdiversity/549629/

Vezner, T. (2018, Jan 17). St. Paul pulls away from 'dockless' bike share proposal over concerns with process. St. Paul Pioneer Press. Retrieved from https://www.twincities.com/2018/01/17/citingproblems-with-process-st-paul-pulls-away-from-dockless-bike-share-proposal/

Vock, D.C. (2018, May 2). Dockless bike shares made a big splash. But where are the riders? Governing. Retrieved from http://www.governing.com/topics/transportation-infrastructure/gov-dockless-bikeshares-low-ridership.html

Wilonsky, R. (2018a, Jan 18). Dallas to bike-share companies: Clean up your mess, or we will. Dallas News. Retrieved from https://www.dallasnews.com/news/dallas-city-council/2018/01/18/dallasto-bikeshare-companies-clean-mess-will

Wilonsky, R. (2018b, Feb 9). 'We got more bikes than we got citizens': Dallas' bike-share crackdown cometh. Dallas News. Retrieved from https://www.dallasnews.com/opinion/commentary/2018/02/09/got-bikes-got-citizens-dallas-bikeshare-crackdown-cometh

Wilonsky, R. (2018c, Apr 10). City council worries proposed permit fees will chase bike-share companies out of Dallas. Dallas News. Retrieved from https://www.dallasnews.com/news/dallas-citycouncil/2018/04/09/city-council-worries-proposed-permit-fees-will-chase-bike-share-companies-dallas Wisniewski, M. (2018a, May 4). Ald. Beale wants Divvy, not dockless, bike share for Far South Side; calls for hearings. Chicago Tribune. Retrieved from http://www.chicagotribune.com/news/local/breaking/ctmet-beale-dockless-bikes-20180503-story.html 
Wisniewski, M. (2018b, May 4). Dockless bike companies protest Chicago's lock rule: 'No other city has required this.' Chicago Tribune. Retrieved from

http://www.chicagotribune.com/news/local/breaking/ct-met-dockless-bike-lock-debate-20180503-

story.html

Yanocha, D. (2018). Optimizing dockless bikeshare for cities [PowerPoint Slides]. Institute for

Transportation \& Development Policy. Retrieved from https://3gozaa3xxbpb499ejp30lxc8-

wpengine.netdna-ssl.com/wp-content/uploads/2018/03/ITDP-2018_Optimizing-Dockless-Bikeshare-for-

Cities.pdf

Young, S. (2018, Feb 27). For now, Dallas remains the bike-share wild west. Dallas Observer. Retrieved from http://www.dallasobserver.com/news/dallas-bike-share-regulations-to-wait-until-the-fall-

10414712 